\title{
Mengajar Anak Secara Alkitabiah menurut Ulangan 6:1-19
}

Ninik Tri Utami ${ }^{1}$, Agustina Dowansiba ${ }^{2}$, Herman $\mathrm{Krey}^{3}$, Erna Surwati Fangidai ${ }^{4}$, Amelia Yembise ${ }^{5}$ 1,2,3,4,5Sekolah Tinggi Teologi Erikson-Tritt Manokwari

\begin{abstract}
Since God formed His people, He wants His people to have a life that is just to Him. Not only for them as parents, but also for children as the next generation of the nation. Teaching children from the time they are young is a must for the people of God. Teaching children is a command from God Himself. Through these verses God commands parents to give earnest instruction to their children. God's purpose in giving this commandment is for God to become a people who really have a real life before His people. Becoming a parent describes what was before. When the children entrusted by God begin to grow up, parents are faced with various personalities. Many parents raise their children without having a good understanding, thus causing the children not to get the correct directions. The book of Deuteronomy 6:1-19 provides a simple but biblical way of teaching children that parents can easily apply to their children, in every opportunity the family has. Few families before had deep understanding experienced many experiences in their children's lives. But in the past 20 years or so, many families have experienced these photos in their children's lives as parents learn to apply the teaching methods taught by the Bible.
\end{abstract}

Keywords: children; Deutronomy 6; parents; teaching

\begin{abstract}
Abstrak: Sejak Allah membentuk umatNya, Dia menginginkan umatNya tersebut memilki hidup yang berkenan kepadaNya. Tidak hanya bagi mereka sebagai orang tua, tetapi juga bagi anak-anak sebagai generasi penerus bangsa. Mengajar anak sejak mereka masih kecil merupakan keharusan bagi umat Allah tersebut. Mengajar anak adalah perintah dari Allah sendiri. Melalui ayat-ayat ini Allah memerintahkan kepada para orang tua agar memberikan pengajaran yang sungguh-sungguh kepada anak-anak mereka. Tujuan Allah memberikan perintah ini adalah agar umat Allah tersebut menjadi umat yang sungguh-sungguh memiliki kehidupan yang benar dihadapanNya. Menjadi orang tua tidaklah semudah apa yang dipikirkan sebelumnya. Ketika anak-anak yang dipercayakan oleh Tuhan mulai beranjak dewasa, beragam persolan yang dihadapi baik oleh orang tua. Banyak orang tua yang membesarkan anak-anaknya tanpa memiliki pemahaman yang baik, sehingga menyebabkan anakanak tidak memperoleh arahan-arahan yang benar. Ulangan 6:1-19 memberikan cara mengajar anak yang sederhana tetapi Alkitabiah yang dengan mudah diterapkan oleh para orang tua kepada anak-anak, dalam setiap kesempatan yang dimiliki oleh keluarga yang ada. Beberapa keluarga sebelum memiliki pemahaman ini banyak mengalami kekacauan dalam kehidupan anak-anak mereka. Tetapi dalam kurun waktu kurang lebih 20 tahun, banyak keluarga mengalami pembaharuan dalam kehidupan anak-anak oleh karena orang tua belajar untuk menerapkan cara mengajar yang dijarakan oleh Alkitab.
\end{abstract}

Kata kunci: anak-anak; orang tua; pengajaran; Ulangan 6

\section{PENDAHULUAN}

Menjadi orang tua masa kini sangatlah sulit daripada yang dihadapi oleh para orang tua pada masa lalu.Di mana-mana banyak keluarga yang sedang membutuhkan pedoman atau petunjuk untuk membesarkan anak-anak. Kemajuan zaman, per- 
kembangan pergaulan yang semakin bebas, kemajuan tehnologi dan banyak hal yang lain. Hal ini sangat mempengaruhi kehidupan anak-anak.

Beberapa keluarga yang mengalami kesulitan dalam mengajar, mendidik anakanak mereka, beberapa tahun tahun kemudian menghadapi anak-anak yang sudah dewasa tetapi memiliki kehidupan yang tidak benar. Hidup yang tidak sungguh mengasihi Tuhan, tidak menyadari bahwa diri mereka memerlukan Tuhan, sehingga menjadi orang dewasa yang tidak mau tahu dengan kehidupan ini. Anak-anak ini harus mendapatkan pengajaran yang benar, yang seharusnya diperoleh dari orang tua mereka. Mengajar dan mendidik anak merupakan sesuatu yang penting yang harus dilakukan oleh orang tua. Sebab dari keluargalah dimulai pendidikan dan pengajaran kepada anak-anak. Orang tua harus sadar bahwa pengajaran kepada anakanak dimulai sejak anak-anak masih kecil, sebab hal ini merupakan dasar bagi pembentukan pribadi anak.

\section{METODE PENULISAN}

Metode Penulisan yang digunakan dalam artikel ini adalah metode penulisan deskripsi. Penulis mendeskripsikan apa yang dikatakan dalam Alkitab secara khusus dalam Ulangan 6:1-19 yang diperoleh melalui buku-buku tetapi juga melakukan penelitian di beberapa keluarga yang dulunya mengalami kesulitan dalam mendidik anak-anak mereka. Seiring berajalannya waktu, keluarga-keluarga tersebut mendapatkan pencerahan melalui pemahaman-peahaman yang terus menerus diajarkan mengenai mengajar anak menurut Alkitab. Anak-anak yang sduah menjadi dewasa pada kahirnya dapat mempelajari dari orang tua mereka, cara mengajarkan anakanak menurut Alkitab sehingga mengalami banyak perubahan oleh karena konsep berpikir mengenai mengajar anak telah diperbaharui dengan mengikuti cara alkitabiah.

\section{PEMBAHASAN}

Kewajiban dan keharusan mengajarkan iman dan perintah-perintah Allah kepada anak-anak, nampaknya belum sepenuhnya diterapkan oleh setiap keluarga. Tuhan telah memerintahkan sejak jaman Perjanjian Lama (PL) bahwa orang tua harus menyampaikan ajaran-ajaran Tuhan kepada anak-anak. Akan tetapi di masa sekarang nampaknya perintah itu tidak begitu dimengerti oleh kebanyakan keluarga Kristen. Memang orang tua perlu dibekali dengan kebenaran firman Tuhan dan pengetahuan yang cukup dan yang praktis dalam mendidik anak. Kadang kala orang tua kehabisan akal dalam menghadapi beberapa anak sekaligus, dengan kebutuhan yang berbeda-beda.

\section{Prinsip-prinsip Pengajaran Anak menurut Ulangan 6:1-19}

Melalui kajian ini penulis akan menguraikan prinsip-prinsip pengajaran dari Kitab Ulangan pasal 6:1-19. Sangat penting untuk mengetahui dan mengerti bahwa pertumbuhan watak anak tidak terpisahkan dari pertumbuhan imannya. B. S. Sidjabat menjelaskan bahwa kalau sejak dini anak sudah dibimbing untuk beriman kepada Allah, dan percaya kepada Kristus, Roh Kudus mengerjakan pembaharuan 
hidup dalam diri anak. Roh itu hadir mendampingi dan memampukan anak dalam pertumbuhan kepribadian. ${ }^{1}$ Pendidikan dan pembinaan karakter menjadi lebih mudah bagi anak karena pekerjaan Allah dalam diri mereka.

Pengajaran adalah hal yang sangat penting bagi anak, agar anak bertumbuh menjadi pribadi yang bukan hanya cerdas tetapi memiliki moral yang tinggi, etika yang baik dan penuh sopan santun. Tuhan sendiri memberi perintah untuk mengajar anak-anak. Alkitab penuh dengan perintah untuk mendidik dan mengajar anak. Firman Tuhan juga memperjelas dan mempertegas bahwa firman Tuhan memiliki kuasa untuk mendidik orang dalam kebenaran.

Prof. S. Nasution mengemukakan pengertian mengajar dalam tiga definisi, pertama, mengajar adalah menanamkan pengetahuan pada anak. Kedua, mengajar adalah menanamkan kebudayaan pada anak. Ketiga, mengajar adalah satu aktivitas mengorganisasi atau mengatur lingkungan sebaik-baiknya dan menghubungkannya dengan anak sehingga terjadi proses belajar. ${ }^{2}$ Pengajaran seharusnya bertujuan untuk mempersiapkan anak-anak dalam menghadapi kenyataan hidup. Allah menciptakan manusia dengan kodrat dan kebutuhan tertentu, dan firman-Nya menetapkan dasar hidup yang membahagiakan, sesuai dengan kebutuhan manusia. Namun, masyarakat yang tidak mengenal firman Allah hanya mengejar mimpi, dalam arti menyimpulkan tujuan dan pola hidup yang tidak sesuai dengan kenyataan. Pengertian dan tujuan hidup bagi orang yang tidak mengenal Allah hanya membawa kesiasiaan, bukan kebahagiaan. ${ }^{3}$

Paulus merumuskan perwujudan tujuan Allah dalam pengajaran ini adalah "Menjadi serupa dengan gambaran Anak-Nya." (Rom 8:29). "Menjadi serupa" berarti adanya satu perubahan yang sungguh-sungguh yang direncanakan dan harus menjadi nyata. Ini sesuai dengan tujuan umum dalam segala pengajaran, yaitu : perubahan dari tidak mengetahui menjadi mengetahui, perubahan dari tidak termotivasi menjadi termotivasi, perubahan dari tidak trampil menjadi trampil. Tujuan umum pengajaran Kristiani mencakup seumur hidup manusia. Menjadi serupa dengan Dia dapat dimulai sejak anak masih kecil dan proses perubahan akan berlangsung terus seumur hidup.

Tujuan pengajaran Kristen adalah meletakkan dasar rohani yang kuat dalam diri seseorang dan membimbing anak dalam mengenal Allah yang benar, hidup dan kasih adanya, mengasihi Dia dengan seluruh eksistensi diri, mengasihi sesama manusia seperti dirinya sendiri. Tujuan Allah untuk menjadikan manusia serupa dengan gambaran anakNya menuntut penggambaran yang benar mengenai Allah, sehingga harus mewarnai semua tujuan yang dirumuskan untuk pelajaran alkitabiah yang diajarkan kepada anak-anak. ${ }^{4}$

${ }^{1}$ B.S. Sidjabat, Membesarkan Anak dengan Kreatif(Yogyakarta : ANDI, 2008),6.

${ }^{2}$ S. Nasution, dikutip oleh, B. S. Sidjabat, Mengajar Secara Profesional (Bandung: Yayasan Kalam Hidup, 2009), 10

${ }^{3}$ W. Stanley Heath, Teologi Pendidikan : Dasar Pelayanan Kepada Anak (Bandung : Yayasan Kalam Hidup, 2005), 39.

${ }^{4}$ Ruth Laufer dan Anny Dick, Pedoman Pelayanan Anak, jil. 1, (Surabaya : YPPII-DEP. PAP, t.t), 70. 
Anak-anak perlu diajar karena mengajar adalah kehendak Allah. Allah sungguh mempedulikan anak. Dalam Ulangan 6:4-7a kita dapat membaca ringkasan dari sepuluh hukum. Hal yang terutama adalah: "Mengasihi Tuhan dengan segenap hati, segenap jiwa dan dengan segenap kekuatan." Hukum pertama ini langsung disusul dengan satu perintah: Ajarkan kepada anak. Menurut Ulangan 6:7 dan Ulangan 11:19 pengajaran tidak terbatas pada waktu dan tempat tertentu melainkan tiap kesempatan dalam kehidupan sehari-hari dapat dipakai untuk mengajar. Anak seringkali bertanya, kagum akan sesuatu, merasa heran atau takut dan gentar. Inilah kesempatan yang baik untuk menyampaikan dengan wajar pesan yang tepat sesuai dengan situasi yang dihadapi.

Tujuan dari pengajaran rohani adalah bahwa Firman Allah ditaruh di dalam hati manusia, bahkan dalam hati anak (Ul. 11:18-19). Tujuan itu diusahakan dalam Perjanjian Lama melalui pengajaran yang tertib dan teliti. Tujuan ini tercapai dalam masa Perjanjian Baru dimana Tuhan sendiri yang menaruh Firman-Nya ke dalam hati manusia melalui Roh-Nya (Yer. 31:33; Ibr. 10:16). Jadi pada waktu mengajar Firman Allah kepada anak, Firman itu ditaruh dalam hati anak. Inilah kehendak Allah.

Tujuan pengajaran yang lain adalah menceritakan dari generasi ke generasi. Mazmur 78:2-8 membuka beberapa rahasia kepada pembaca. Hati pemazmur meluap-luap mengenai perbuatan Tuhan yang mengherankan, bukan hanya yang dia alami tetapi juga yang diceritakan nenek moyangnya. Kepada siapakah Daud mewariskan pengalaman hatinya ini? Kepada generasi berikutnya supaya mereka juga mengetahuinya. Demikian juga umat Tuhan zaman ini. Tiap generasi mempunyai tugas menyampaikan perbuatan Tuhan kepada generasi berikutnya. Untuk itu keluarga dan gereja harus bekerjasama. Dari hal yang baru diselidiki jelas terlihat bahwa pengajaran seteliti itu dimulai di rumah tangga. Tuhan berjanji bahwa Firman-Nya tidak akan kembali dengan sia-sia, melainkan akan beroperasi dalam hati orang yang mendengarnya. Demikian juga dengan anak yang diajar. Seringkali kita takut bahwa anak yang percaya kepada Tuhan Yesus tidak akan tetap dalam iman mereka. Tetapi Firman Tuhan berjanji bahwa anak yang diajarkan jalan Tuhan tidak akan menyimpang daripadanya pada masa tuanya (Ams. 22:6).

Keinginan dan kerinduan untuk melayani anak adalah hal yang sangat baik, karena Tuhan sendiri menghendaki agar anak-anak diajar; anak-anak membutuhkan Juruselamat dan Tuhan memberi janji bahwa ada akibat yang besar dan kekal dalam kehidupan anak yang percaya. Ulangan 6:1 yang berbunyi "Inilah perintah, yakni ketetapan dan peraturan, yang aku ajarkan kepadamu atas perintah Tuhan, Allahmu, untuk dilakukan di negeri, kemana kamu pergi untuk mendudukinya." Dan Ulangan 6:4-5 yang berbunyi: "Dengarlah, hai orang Israel: Tuhan itu Allah kita, Tuhan itu Esa! Kasihilah Tuhan Allahmu, dengan segenap hatimu, dan dengan segenap jiwamu, dan dengan segenap kekuatanmu." Kedua ayat ini disebut oleh Musa sebagai perintah, yakni: ketetapan dan peraturan. "Ketetapan" yang berarti "ketentuan atau kepastian" sedangkan "peraturan" yang berarti "petunjuk atau kaidah 
atau ketentuan." Perintah ini datangnya dari Allah. Ini berarti merupakan perintah yang sangat penting yang harus diajarkan dan dilakukan oleh umat Israel. Perintah ini sifatnya urgent, tidak dapat tidak dilakukan. Perintah ini mengandung pengajaran yang sangat penting untuk kehidupan umat Israel.

Secara esensi yang dikehendaki Allah dalam bagian ini ialah ketaatan umat. Adapun fondasi ketaatan ialah dengan mendengar kebenaran Allah. "Maka dengarlah, hai orang Israel! Lakukanlah itu dengan setia, supaya baik keadaanmu, dan supaya kamu menjadi sangat banyak, seperti yang dijanjikan TUHAN, Allah nenek moyangmu, kepadamu di suatu negeri yang berlimpah-limpah susu dan madunya (6:3)." Fondasi ketaatan dimulai dengan mendengarkan-dengan mendengar firman. Mendengar adalah perlindungan terhadap ketakutan dan pengerasan hati (Ibr. 3:7). Ayat-ayat ini ditujukan kepada bangsa Israel. Tetapi pada khususnya, ditujukan kepada orangtua-terutama kepada para ayah dan para kakek oleh karena peran kepemimpinan mereka menurut Kitab Injil, dan oleh karena tanggung jawab para orangtua di dalam pengabadian iman pada anak-anak mereka. Hal ini jelas dari konteksnya (bdk. ay. 2, 7, 20).

Tujuan mendengar Firman adalah untuk mengenal Allah."Dengar" dalam bahasa Ibrani adalah shema yang berarti "untuk mendengar dan memahami, atau untuk mendengar dengan sikap cerdas atau tajam artinya bisa membedakan." Mendengar Firman jangan pernah merosot ke dalam formalitas religius atau ke dalam sebuah rutinitas yang religius dimana umat sekedar memberikan 'anggukan kepada Allah,' tetapi setelah itu dengan segera melupakan Allah (bdk. Mzm 50:22). Ayat tersebut akan menunjukkan, bahwa tujuan mendengar Firman dan kebenaran-Nya adalah untuk benar-benar mengenal Allah dengan intim dan secara pribadi, untuk benarbenar memahami kebenaran Alkitab sehingga menjadi arti dan tuntunan kepada hubungan yang pribadi dengan Tuhan. Sebab manusia "tidak hidup dari roti saja, tetapi oleh setiap Firman yang keluar dari mulut Allah." Dengan demikian manusia perlu untuk hidup oleh Firman Allah sehingga bisa mengenal Allah secara pribadi dan meletakkan kepercayaan di dalam-Nya.

Dengan memiliki pengenalan akan Allah baik, maka manusia akan semakin menyadari bahwa ia memiliki banyak kekurangan pengetahuan akan Allah. Dengan kerendahan hati dan sikap menyembah, manusia harus belajar untuk mengukur diri sendiri, bukan oleh pengetahuan tentang Allah, bukan oleh berapa banyak ayat yang dapat dihafalkan dalam ingatan, bukan oleh karunia-karunia atau talenta-talenta atau pelayanan, tetapi dengan keintimannya lewat berdoa, bagaimana iabergaul dengan Tuhan dalam perkataannya, dengan apa yang terus ada dalam hati, dan oleh tingkat ketaatan dalam firmansesuai dengan apa yang diketahuinya.

"Dengarlah, hai orang Israel: TUHAN itu Allah kita, TUHAN itu esa! Kasihilah Tuhan Allahmu dengan segenap hatimu dan dengan segenap jiwamu dan dengan segenap kekuatanmu." Bagian ini didahului oleh kata Ibrani, shema. Kata shema berarti "dengarlah." Shema adalah dogma fundamental dari Perjanjian Lama yang oleh Tuhan Yesus disebut sebagai yang paling penting dari semua hukum (Mrk. 12:29-30). Perikop ini memakai bentuk tunggal yang fungsinya sebagai kata pen- 
dahuluan untuk uraian-uraian berikutnya. Oleh sebab itu, menuntut keseriusan yang penuh dari pihak pendengar. Kalimat "TUHAN itu Allah kita, TUHAN itu esa", merupakan tuntutan supaya Israel mengabdi kepada TUHAN dengan kesetiaan yang total. Sebagaimana dijelaskan diatas bahwa dalam tradisi Yudaisme, Ulangan 6:4 menjadi suatu pengakuan iman yang wajib diucapkan tiap pagi dan malam. Pengakuan ini, yang disebut "shema."

Shema, Ulangan 6:4-9 berisi apa yang disebut sebagai "kebenaran yang pokok dari agama Israel" dan "kewajiban pokok yang ditemukan di atasnya" Kebenaran yang pokok bertalian dengan "keesaan" Allah (isi ayat. 4), yang pada akhirnya akan diperinci dalam doktrin monoteisme. Kewajiban yang pokok adalah tanggapan akan kasih yang Allah tuntut dari umat (ay 5). Dalam isi ayat 6-9 hubungan dua tema ini dengan komunitas itu diperinci. "Perkataan ini", yaitu kitab Ulangan adalah untuk dikenal oleh setiap anggota, orang dewasa dari komunitas tersebut, dan untuk mengajar hal kerajinan kepada anak-anak mereka. Tidak ada hal yang lebih penting bagi masa depan orang-orang kepunyaan Allah daripada komunikasi dari "perkataan ini."5

Dua dari Kitab Injil menambahkan kata "akal budi" pada "hati”, "jiwa" dan "kekuatan" (Mrk. 12:30, Luk 10:27), dan Matius 22:37 menyebut "akal budi" di tempat "kekuatan." Pengajaran pokoknya ialah bahwa orang Israel harus mengasihi Allah dengan segenap jiwa raga mereka, termasuk akal budi, menyimpan perkataan Allah di dalam hati dan akal budi mereka dengan perintah untuk mengikatkannya sebagai simbol pada lengan dan dahi mereka. ${ }^{6}$ Musa mungkin mengatakan bahwa yang terakhir itu dipahami secara kiasan dan bukan secara harfiah. Orang Israel tidak diwajibkan menuliskan perintah-perintah Tuhan pada ambang pintu rumah mereka, tetapi pikiran mereka yang harus dipenuhi dengan hukum dan ketetapan Tuhan sehingga segala percakapan dan kegiatan mereka harus dikuasai oleh firman itu. Apabila hal ini betul-betul terjadi, maka Israel akan mendiami Kanaan selama bertahun-tahun yang akan datang dan menikmati berkat-berkat Allah (11:12). ${ }^{7}$

Pemberian simbol pada dahi dan tangan, pada masa kini tidaklah diterapkan atau dibiasakan. Pada intinya setiap anak Tuhan haruslah memiliki hati dan pikiran yang selalu terpaut kepada Allah sebagai bentuk mengasihi Allah. Itu berarti segala eksistensi kehidupan ini hanya untuk kemuliaan Allah saja. "Engkau harus mengasihi Yahweh Allahmu" - perintah untuk mengasihi termasuk bahasa perjanjian dari Timur Dekat Kuno. Ini juga merupakan karakteristik kiasan Bapa/anak yang digunakan di tempat lain dalam kitab Ulangan. Perintah untuk mengasihi Allah didasarkan pada sesuatu yang dapat dijadikan teladan dari kasih utama Allah.

"Dengan segenap hatimu dan dengan semua jiwamu, dan dengan segenap kekuatanmu." Manusia dipanggil untuk mengasihi Allah dengan keseluruhan diri

${ }^{5}$ Christensen, Duane L., Word Biblical Commentary, vol. 6: Deuteronomy 1-11 (Dallas, Texas: Word Books, Publisher, 1998).

6Herbert Wolf, Pengenalan Pentateukh (Malang : Gandum Mas, 2004), 229-300.

7Ibid., 300. 
mereka (bdk. 4:9, 29; 10:12). Meskipun kata Ibrani yang berarti "hati," ini bukanlah organ/bagian badan secara fisik seperti halnya di dalam konteks ini tetapi lebih kepada apa yang disebut sebagai pikiran. Pasangan dari " hati," dan "jiwa," menyatakan bahwa suatu perbedaan dari beberapa jenis sedang dibuat antara mental dan energi dan aktivitas secara emosional. Dalam istilah kedalaman psikologi modern, kita akan mengatakan bahwa kasih kita kepada Allah adalah untuk merangkul keseluruhan pikiran kita, kedua-duanya pikiran tak sadar dan yang sadar. Disiplin diri diperlukan, dalam arti bahwa kita mengasihi Allah dengan segenap kekuatan kita. Kasih yang mencakup semua kepada Allah akan menemukan ungkapannya dalam ketaatan penuh kegembiraan kepada perintah-perintah Allah.

Ayat 6 menegaskan bahwa umat Israel harus dengan serius memperhatikan perintah untuk mengasihi Tuhan dengan segenap hati. Perintah ini bukanlah perintah biasa, tetapi perintah yang mutlak. Melalui perintah ini Allah benar-benar menginginkan bahwa firman-Nya tersimpan di dalam hati umat-Nya. ${ }^{8}$ Di dalam hati yang diperbaharui, Allah menciptakan keinginan untuk mengasihi dan mentaati Dia. Berulang kali Allah menekankan kepada umat-Nya pentingnya kasih yang timbul dari hati. Kasih dan pengabdian kepada Allah tidak dapat dipisahkan dari ketaatan kepada hukum-hukum-Nya. Dengan demikian mengasihi Tuhan hendaknya dilakukan dengan hati yang sungguh-sungguh oleh karena hal ini sangatlah penting.

"Haruslah engkau mengajarkannya berulang-ulang kepada anak-anakmu," (ayat 7). Diperlukan kepedulian dan kerajinan dan bersusah payah, untuk mengajari anak-anak, secepat kemampuan mereka, di dalam pengetahuan tentang Allah, dan perintah-perintah-Nya; agar mereka mengasihi Dia, takut akan Dia, melayani, dan menyembah-Nya, inilah yang membawa mereka ke atas di dalam pemeliharaan dan peringatan akan Tuhan. Salah satu cara utama untuk mengungkapkan kasih kepada Allah ialah mempedulikan kesejahteraan rohani anak-anak dan berusaha menuntun mereka kepada hubungan yang setia dengan Allah. Pembinaan rohani anak-anak seharusnya merupakan perhatian utama semua orang tua. Orang percaya harus dengan tekun memberikan kepada anak-anaknya pendidikan yang berpusatkan Allah dimana segala sesuatu dihubungkan dengan Allah dan jalan-jalan-Nya. ${ }^{9}$

"Dengan berulang-ulang" ayat ini menandai adanya pengajaran bukan sekali, dalam-satu waktu atau suatu usaha yang satu kali, tetapi berkelanjutan terus sepanjang waktu. Rahasia untuk belajar adalah mengulangi. ${ }^{10}$ "Dan membicarakannya apabila engkau duduk di rumahmu,"Kalimat pendek ini menunjuk pada setiap kesempatan atau setiap waktu, misalnya pada waktu makan, atau pada jam santai, atau bahkan ketika mengerjakan pekerjaan di dalam rumah. Cara ini adalah cara yang dapat diterima. Setiap peluang harus diambil untuk menanamkan pengetahuan tentang hal-hal yang ilahi ke dalam pikiran anak yang lembut. Pengarahan rohani

${ }^{8}$ Alkitab Penuntun Hidup Berkelimpahan (Malang : Gandum Mas,2004), 285.

9Ibid., 285.

10J.Hampton Keathley III, Tanggung Jawab Kebapaan (Ulangan 6:1-19), hamptonk3@bible.org, 
harus berpusat di rumah dan melibatkan ayah dan ibu. Pengabdian kepada Allah di dalam rumah tangga wajib dilakukan. Hal itu adalah perintah langsung dari Tuhan.

"Apabila engkau sedang dalam perjalanan." Dalam sebuah perjalanan yang disertai oleh anak-anak, atau ketika berekreasi, di kebun, ladang, gunung atau laut. Kesempatan tersebut dapat diambil dengan melihat berbagai hasil ciptaan untuk memimpin ke dalam suatu ceramah mengenai Allah, ciptaan-Nya, sifat-Nya, kesempurnaan-Nya, dan pekerjaan-Nya, dan kewajiban setiap ciptaan-Nya untuk mengasihi, takut akan Dia, dan melayani-Nya. "Ketika engkau berbaring dan apabila engkau bangun." Pada waktu akan pergi tidur, dan bangun dari tempat tidur; waktuwaktu tersebut merupakan waktu dimana cara berdoa kepada Allah, bisa diperbaiki dengan memberikan instruksi kepada anak-anak.

Ceramah yang saleh mengenai pengajaran tentang mengasihi Allah, harus dinyatakan oleh para orang tua, dengan penuh penghormatan dan kesungguhan hati, karena manfaat tidak hanya terhadap anak-anak, tetapi terhadap rumah tangga, para sahabat dan rekan-rekan di tempat kerja, atau pada saat pertemuan, atau saat menerima kunjungan, dan ketika berjalan-jalan/rekreasi, atau dalam percakapan, di dalam perjalanan-perjalanan, ketika beristirahat dari segala pekerjaan rumah untuk berbaring tidur, dan ketika pagi-pagi engkau bangun dan kembali kepada keluarga.

"Haruslah juga engkau mengikatkannya sebagai tanda pada tanganmu,..” Sebagai seorang manusia yang mengikatkan sesuatu pada tangannya sebagai suatu tanda, di mana ia mungkin mengingat sesuatu yang ia rindukan; meskipun demikian Bangsa Yahudi memahami hal ini secara harfiah, tentang mengikat sebuah gulungan kertas perkamen, pada bagian ujung yang satu dan yang lainnya sedangkan tulisannya ditulis di dalamnya, di atas tangan kiri mereka. "Dan haruslah itu menjadi lambang di dahimu," di mana rumbai-rumbai, yang dipakai oleh bangsa Yahudi diatas dahi mereka, dan di tangannya. Ulangan 6:8, 9, kemungkinan bahwa pada waktu itu ada sedikit atau beberapa salinan yang tertulis dari keseluruhan hukum. Hanya di pesta tabernakel hukum tersebut dibacakan kepada mereka; dan oleh karena itu Allah menetapkan mereka untuk menulis sebagian kalimat yang dipilih dari hukum, yang paling penting dan menyeluruh, di atas dinding mereka, atau di gulungan-gulungan dari kertas perkamen yang dikenakan di sekitar pergelangan tangan mereka, dan karenanya sebagian orang berpikir rumbai-rumbai yang sangat banyak digunakan di antara orang Yahudi.

Ini juga mengisyaratkan bahwa kita jangan pernah malu untuk memiliki agama kita, maupun untuk memiliki diri kita sendiri di bawah pengawasan dan pemerintahan olehnya. Biarlah itu tertulis di gerbang-gerbang kita, dan membiarkan semua yang lewat pintu kita membacanya, bahwa kita percaya Yahweh untuk menjadi Allah saja, dan percaya diri kita sendiri harus mengasihi Dia dengan segenap hati kita.

"Dan haruslah engkau menuliskannya pada tiang pintu rumahmu dan pada pintu gerbangmu."Untuk mengingatkan kepada mereka ketika mereka ke luar dan 
masuk ke dalam, sehingga mereka bisa berhati-hati untuk mematuhinya. Bangsa Yahudi memahami ini secara harfiah juga, dan menuliskan bagian ini dalam sebuah gulungan kertas perkamen dengan beberapa kutipan teks pendek, dan di sini Targum Yonathan, memperbaikinya ditiga tempat, berhadapan dengan kamar tempat tidur, di atas tiang- tiang rumah, dan di gerbang sebelah kanan; dan inilah yang mereka sebut Mezuzah; dan inilah nama yang diberikan baginya. Kertas perkamen disediakan untuk tujuan, mereka menulis kata-kata di Ulangan 6:4 dan kemudian menggulungnya kertas perkamen ke atas, dan menulis di atasnya "Shaddai"; dan menaruhnya dalam rotan atau alang alang, jika tidak ke dalam bagian kayu yang berongga, dan mengikatkan nya pada tembok di tiang- tiang pintu di sebelah kanan dari pintu masuk; dan dengan seperti itu, setiap kali mereka keluar masuk, mereka menjadikannya sebagai bagian dari pengabdian mereka untuk menjamah kertas perkamen ini, dan menciumnya.

Fokus dalam mengajar anak-anak "perkataan-perkataan ini" dengan rajin dalam konteks keluarga pada waktu dan tempat yang dapat dipikirkan, menjelaskan sekali lagi tujuan yang bersifat pendidikan dari kitab Ulangan. Isi dari kitab ini adalah kurikulum yang utama dalam satu program yang berkelanjutan dari pendidikan yang religius pada bangsa Israel di masa lampau. Pemakaian rumbai-rumbai dan mezuzoth merupakan perkakas yang bersifat pendidikan yang sangat utama, yang dirancang untuk menjaga agar pernyataan-pernyataan ringkasan yang besar dari "perkataan-perkataan Yahweh" menjadi pokok dalam pengalaman tiap anggota individu komunitas perjanjian. ${ }^{11}$

Kebaikan-kebaikan Allah merupakan dasar bagi umat untuk tidak melupakan Tuhan. Bangsa Israel diminta untuk merenungkan perjalanan mereka yang penuh liku-liku, akan tetapi penyertaan Tuhan begitu nyata bagi mereka. Berkat-berkat Tuhan yang melimpah yang menantikan mereka harus menjadi dasar bagi mereka untuk selalu mengingat penyertaan Tuhan yang luar biasa. Demikian pun bagi para orang tua yang dengan rajin dan setia memberi pengajaran kepada anak mengenai kebaikan-kebaikan Tuhan, akan menolong anak untuk mengerti dan mengingat bagaimana Tuhan menolong mereka dalam hidup keseharian dan dalam keluarga masing-masing. Menolong anak untuk menyadari dan merasakan bahwa sungguhsungguh Allah telah turut campur tangan dalam kehidupan anak itu sendiri dan keluarganya. Secara khusus anak dapat mengucap syukur atas keselamatan yang telah mereka miliki.

Tujuan dari pengarahan oleh orang tua ialah mengajar anak-anak untuk takut akan Tuhan, berjalan pada jalan-Nya, mengasihi dan menghargai Dia, serta melayani Dia dengan segenap hati dan jiwa. Pengalaman di Horeb dalam Ulangan 4 dirancang untuk menghasilkan sebuah pemujaan yang takut Allah dalam hati manusia sehingga perjanjian antara mereka dan Allah menjadi mungkin. Dalam Perjanjian Lama takut akan Allah lebih dari perasaan kagum atau penghormatan, meskipun demikian kedua-duanya termasuk di dalamnya. Takut akan Allah berarti menjadi benar-benar

${ }^{11}$ Duane, Word Biblical, 1998. 
mengetahui tentang kemurnian moral dan kemahakuasaan-Nya sehingga manusia benar-benar takut untuk menentang-Nya. Takut akan Allah juga termasuk menanggapi-Nya dalam penyembahan, pelayanan, kepercayaan, ketaatan, dan komitmen.

Anak-anak yang sudah memiliki hubungan yang dekat dengan Allah dan mengerti akan kasih Allah bahkan pernah mengalami kasih Allah pasti di dalam hatinya memiliki kerinduan untuk beribadah. Pengalaman yang menyenangkan bertemu dengan Tuhan dalam satu titik pertemuan yang indah membawa anak-anak kepada takut akan Tuhan dan kerinduan untuk dekat dengan Tuhan. Kerinduan untuk dekat dengan Tuhan merupakan modal utama untuk anak-anak senang beribadah. Ibadah yang menarik dan tidak membosankan merupakan hal yang sangat baik untuk tmembawa mereka dalam acara pertemuan antara anak dengan Tuhannya.

Ibadah adalah hubungan dengan Tuhan. Hubungan yang harmonis dengan Tuhan haruslah nyata dalam hubungan yang harmonis dengan sesama manusia, sebab itu adalah cerminan bagi hubungan yang baik dengan Tuhan. Ibadah berpusat kepada Allah dan bukan kepada manusia. Dalam ibadah Kristen, kita menghampiri Allah dengan bersyukur karena apa yang telah dilakukan-Nya bagi kita di dalam Kristus dan melalui Roh Kudus. Ibadah menuntut iman dan pengakuan bahwa Dialah Allah dan Tuhan kita. Bagi anak-anak, kemungkinan kesadaran ini belumlah dimilikinya tetapi paling tidak anak-anak memiliki kesukaan untuk dekat dengan Tuhan dalam ibadah itu. Dua prinsip pokok yang menentukan ibadah Kristen ialah penyembahan yang sesungguhnya yang terjadi dalam roh dan kebenaran (Yoh 4:23). Maksudnya adalah penyembahan harus dilakukan sesuai dengan penyataan diri Allah didalam putra-Nya.

Aplikasi bagi anak-anak mengenai ibadah ialah anak-anak dapat diajar untuk menyembah dan mengucap syukur kepada Allah melalui puji-pujian. Semua anak senang untuk memuji Tuhan melalui nyanyian. Lagu-lagu dan musik dapat menarik anak-anak untuk datang kepada Tuhan. Porsi dalam ibadah anak atau sekolah minggu harus penuh dengan pujian, sebab puji-pujian itu akan membawa anak kepada firman Allah dan dalam doa. Puji-pujian mempersiapkan anak untuk menerima kebenaran firman Allah. Musa mengingatkan agar mereka jangan beribadah kepada allah lain. Allah secara tegas dan jelas melarang bangsa itu untuk terlibat dengan salah satu dewa berhala di Kanaan. Dia sungguh-sungguh akan cemburu mempertahankan kehormatan nama-Nya. ${ }^{12}$ Allah menghendaki kekudusan hidup dari umat Allah. Dan umat-Nya harus hanya menyembah Dia saja.

Bila pengajaran dilaksanakan dengan benar, pasti ada dampak yang sangat baik bagi kehidupan anak. Tentu saja dampak pengajaran akan menghasilkan hidup yang diberkati. Kebaikan dan berkat adalah akibat dari melakukan apa yang benar dimata Tuhan. Perintah untuk mengasihi Tuhan dengan segenap hati, dengan segenap jiwa dan dengan segenap kekuatan, bila dengan rajin dan tekun dan terus menerus diajarkan kepada anak, akan menjadi pola bagi anak untuk tetap mengasihi

${ }^{12}$ Meredith G. Kline, The Wycliffe Bible Commentary, vol. 1 (Malang: Gandum Mas, 2004), 453. 
Tuhan. Sekalipun dalam menjalani hidupnya dan dalam mencari jati dirinya, anakanak harus jatuh bangun dalam menemukan dirinya sendiri di hadapan Allah. Akan tetapi pola mengasihi Tuhan sudah ada di dalam hatinya. Dengan demikian berkatberkat Tuhan sudah mengikutinya. Ayat 18-19 mencatat berkat-berkat yang menyertai orang-orang yang melakukan apa yang benar dan baik di mata Tuhan. Berkat pertama adalah, "supaya baik keadaanmu”. Kehidupan anak-anak Tuhan, selalu ada dalam keadaan yang baik. Belum pernah ada anak Tuhan yang hidup mengasihi Tuhan dan melakukan kebenaran dan kemudian hidupnya kacau balau. Suatu hidup yang penuh keberkatan. Anak-anak Tuhan bisa menikmati segala berkat dari Tuhan, kadang-kadang berkat itu tanpa disangka-sangka dan Tuhan telah mempersiapkannya bagi anak-anak yang takut akan Dia. Berkat ketiga adalah Tuhan mengusir semua musuh. Anak Tuhan cinta akan perdamaian, sehingga satu orang musuh sudah terlalu banyak bagi seorang anak Tuhan. Itu berarti anak Tuhan akan gelisah dan tidak tenang ketika ada persoalan yang tidak diselesaikan, sehingga mendorong dia agar sesegera mungkin menyelesaikan

\section{KESIMPULAN}

Sebelum mengetahui cara mendidik anak menurut Alkitab, banyak orang tua yang mengalami kendala ketika mengajar anak-anak mereka. Orang tua melakukannya menurut apa yang mereka pandang baik dan itu dapat saja merupakan ajaranajaran yang benar. Tetapi Alkitab melalui Kitab Ulangan 6: 1-19 menyajikan cara yang alkitabiah, sederhana dan mudah dalam mengajar anak-anak kita. Orang tua harus mengajar ketetapan Tuhan itu dengan berulang-ulang oleh karena anak mudah lupa untuk sesuatu yang baru saja didengar. Orang tua harus mengajarkannnya secara turun temurun, dari generasi ke generasi. Dalam setiap kesempatan dapat merupakan moment yang baik untuk mengajarkan ketetapan Tuhan itu. Pada waktu duduk, pada waktu berjalan, pada waktu berbaring, dan dimana saja dapat mengajarkan ketepapan Tuhan. Cara mengajar seperti ini membutuhkan ketekunan sehingga jangan bosan mengajarkannya. Ketika orang tua mulai memahami ini, anak-anak nampak lebih terbina secara rohani sehingga setelah mereka dewasa mereka menjadi anak-anak yang terdidik oleh kebenaran firman Tuhan. Generasi berikutnya memahami hal ini sehingga menerapkan dalam kehidupan keluarga mereka. Untuk melihat hasil dari penelitian ini, dibutuhkan waktu yang cukup lama, tetapi proses itu memberikan hasil yang baik oleh karena generasi berikutnya menerapkan cara ini untuk mengajar anak-anak mereka.

\section{REFERENSI}

Alkitab Penuntun Hidup Berkelimpahan. Malang : Gandum Mas,2004.

Christensen, Duane L., Word Biblical Commentary, vol. 6: Deuteronomy 1-11 (Dallas, Texas: Word Books, Publisher, 1998).

J.Hampton Keathley III, Tanggung Jawab Kebapaan (Ulangan 6:1-19), hamptonk3@bible.org, 1Herbert Wolf, Pengenalan Pentateukh Malang : Gandum Mas, 2004.

Meredith G. Kline, The Wycliffe Bible Commentary, vol. .Malang: Gandum Mas, 2004. 
S. Nasution, dikutip oleh, B. S. Sidjabat, Mengajar Secara Profesional. Bandung: Yayasan Kalam Hidup, 2009.

Ruth Laufer dan Anny Dick, Pedoman Pelayanan Anak, jil. 1. Surabaya : YPPII-DEP. PAP, t.t.

W. Stanley Heath, Teologi Pendidikan : Dasar Pelayanan Kepada Anak. Bandung : Yayasan Kalam Hidup, 2005.

B.S. Sidjabat, Membesarkan Anak dengan Kreatif.Yogyakarta : ANDI, 2008. 